\title{
PRIORITIES OF HIGHER EDUCATION IN POLAND AND IN EUROPE
}

\author{
Malgozhata Kaminska \\ $\mathrm{PhD}$ \\ Lecturer at Higher School named after Pavel Vlodkovich in Plock, Poland \\ gosiam0@poczta.onet.pl \\ $+48509604012$
}

\section{ABSTRACT}

The article presents an analysis of the most important priorities for higher education in Poland and in Europe. The main objectives and tasks are outlined on the basis of the selected strategic documents, reports and statements of various Polish and international bodies interested in education at a higher level. Challenges for higher education in Poland and Europe relate to different dimensions. First of all, issues related to the quality of education and its accessibility, organizing the education process and financing, as well as research and development activities in national and international scale come to the fore. An important priority is connecting of learning outcomes with the labour market. These challenges arise from the plan to build an economy based on knowledge and innovation, as well as continuing the concept of learning throughout life.

Keywords: Poland; priority; strategy; higher education; the European Union.

\section{INTRODUCTION}

In the last two decades in Poland and in Europe has considerably increased the demand for higher education. Enrolment ratios in Polish higher education have increased more than fourfold. According to the CSO data, in the academic year 1990/1991 it was 9.8 percent, in the years $2010 / 2011-40.6$ percent. In the academic year 2010/2011 the number of students reached 1841.3 thousand, of which full-time students were 68.5 percent of all, and the part-time students were 31.5 percent. Since 2005/2006, when the number of students in Poland reached a record high of 1953.8 thousand - the number of students has been steadily decreasing, although the scale of this decline is quite small. The main reason for this decline is entering the age of higher education - people from the bottom of birth-rate, which dates back to the late 80th of the XX century (IBE, 2012: p. 126). The increase in the number of students is the result of the dissemination of the idea of higher education as well as the result of development of a system of non-public schools in Poland that began in 1990. In 2013, Poland had 140 public universities and 307 private universities (Higher Education, 2013: p. 10).

In 2013 in Europe 37 percent of EU citizens aged 30-34 completed studies. For comparison, according to the data of 2002, it was only 24 percent. Between 2002 and 2013 the percentage of people aged 30-34 who completed higher education, more than doubled in ten European countries: Poland (from 14.4 percent to 40.5 percent), Malta (from 9.3 percent to 26 percent), Slovakia (from 10.5 to 26.9 percent), Romania (from 9.1 percent to 22.8 percent), Latvia (17.3 to 40.7 percent), Portugal (from 13 percent to 29.2 percent), Luxembourg (from 23.6 percent to 52.5 percent), Hungary (from 14.4 percent to 31.9 percent), Lithuania (from 23.4 percent to 51.3 percent) and the Czech Republic (from 
12.6 percent to 26.7 percent). Most people aged 30-34 years with academic degrees were found in Ireland (52.6 percent), Luxembourg (52.5 percent), Lithuania (51.3 percent), Sweden (48.3 percent), Cyprus (47.8 percent) and the UK (47.6 percent). On the other hand, the fewest number of people with higher education was recorded in Italy (22.4 percent), Romania (22.8 percent), Croatia (25.9 percent) and Malta (26 percent) (OECD, 2014).

Higher education is undoubtedly a strong asset on the labour market. The chances of getting a job and the correlation of the average earnings of college graduates to the average wage of secondary school leavers in the country are much higher, and the bonus wage for higher education in Poland is high compared with other countries of the OECD (E \& YB IBGR, 2009: p. 8). The result of the Social Diagnosis showed that the vast majority of households in Poland in 2015 wanted their children to complete a university master's degree (over 73 percent). While almost 13 percent of the households found a sufficient level of education for their children completing a technical school or a professional lyceum, and almost 11 percent - higher professional school (Bachelor's degree) (Chapinski, Panek, 2015: p. 104). Both in terms of the unemployment rate and in terms of the percentage of employment among young people (25-29 years) with higher education, Poland is close to the average level recorded in the whole European Union. In the group of European Union countries a greater difference between people with higher and secondary education has taken place in the last five years only in Lithuania, Ireland, Romania and Hungary. The analysis of the data by region shows that people with higher education work more and have less problems finding a job, regardless of the province (MNiSW, 2013: p. 56).

Equalization is higher education in Poland and in Europe and the rapid growth of enrolment rates is one of the most important trends in education of the past two decades. This phenomenon was the result of progressive political, economic and social changes. At the turn of the XX and XXI centuries higher education became a subject of interest to many bodies of the European Union that carried out a broad overview of the state of higher education. The result of the research and analysis was the working out of the reports and strategies, defining the most important directions of development in the coming decades perspective.

\section{SOCIAL AND ECONOMIC GROUNDS OF HIGHER EDUCATION TRANSFORMATION}

Linking of the world of economy, social policy and education policy is a phenomenon which significantly determines the approach to education and obtaining the knowledge. Globally, for some time already we have been dealing with the transformation of the economy based on materials science and production into the economy based on the knowledge, technology and innovation. According to Teresa Heynitska - Bezvinska "the development of information technologies in the twentieth century meant that currently we are dealing with the civilization excess data, information and knowledge that an average person can receive the information chaos, cognitive relativism, ethical and aesthetic anarchy, loss of the existing points of support in exploring and evaluating. These indicators of idiosyncratic kind of "embarrassment" of a modern person - according to many opinion leaders - have confirmed the need to build a knowledge-based society, or - according to others - post-industrial society, global, netting, informational and 
so on" (Heynitska - Bezvinska, 2008: p. 29). Dynamically developing information society in which commodity information becomes treated as a special good asset, equivalent or even more valuable than material possessions. The educational function of the information society is the dissemination of scientific knowledge and awareness of the importance of skills.

The development of the information society, globalization and the transformation of civilization, science and technology are the main factors influencing the shape of modern education. The authors of the White Paper on education and training and Teaching and learning - on the road to a learning society since 1995 have been showing the problem of knowledge and ways of its transmission so that one could quickly adapt to the needs of the labour market and plan their careers better. Attention is also drawn to the fact that economic growth, even though it is a key issue and should be a driving force for all projects, is not enough to reduce the phenomenon of unemployment and the frustration of European societies. The aim should be to invest in people and their knowledge, build learning society (Bednarek, 2003: pp. 357-358) programs. It is stated unequivocally that "in modern European society, there are three duties, namely: social integration, development of fitness for employment and personal development are integral." Knowledge is the most important raw material of the third revolution of social information - sought-after commodity, a product, and a symbol a computer (Bednarek, 2003: p. 357-358). The prospects of development of countries and regions are increasingly decided by intellectual potential and knowledge related to the latest achievements of the modern science, especially of exact, technical sciences. The construction of the "new economy" in which the key role is played by knowledge and innovation, is becoming in the XXI century the primary challenge for countries seeking to achieve a high level of development and competitiveness. (...) The most advanced in the construction of the knowledge-based economy are among the others the United States of America, Japan, Singapore, South Korea and Finland. The European Union Member States, although having already achieved much in the way to build a knowledge-based economy and being classified among the richest and most technologically advanced countries in the world, still must overcome many barriers to catch up the development in relation to such countries as the United States of America or Japan (EPIiR, 2016).

\section{THE LISBON STRATEGY AND THE BOLOGNA PROCESS}

The idea of building the economy and a knowledge society has a key role in socio-economic policy in Europe. In 2000, the European Council adopted a 10-year program called the Lisbon Strategy. Its aim was to make the EU by 2010 the most competitive and dynamic knowledge-based economy in the world, capable of sustainable economic growth with more and better jobs and greater social cohesion. The modernization of the European social model took place, inter alia under the "Education for life and work in the knowledge society" program. Expected was the increase of innovativeness in EU countries by stimulating research and development towards increased spending on $\mathrm{R} \& \mathrm{D}$ to 3 percent of GDP by 2010, the free movement of knowledge, researchers and technology. This also included the modernization of the system of higher education: funding research units, supporting R \& D projects, the flow of students and international exchange of scientists (Cherwinska, 2004: p. 2). 
Presumptions of the Lisbon Strategy refer indirectly to other important initiatives on the reform of higher education in Europe. In 1999, the Bologna Declaration was signed and the challenge of creating the European Higher Education Area in the context of the so-called Bologna Process was taken. In the Declaration outlined are the key priorities for higher education:

- $\quad$ increasing the "employability" (employability) of university graduates and education adaptation to the labour market expectations;

- increasing the mobility of citizens, including students, graduates and teachers;

- $\quad$ inclusion of graduates in the process of building a civil society;

- broadening the access to universities offering education of the highest quality;

- $\quad$ promoting learning throughout life;

- building a synergistic relationship between education and scientific research;

- increasing the competitiveness and attractiveness of European higher education systems and understanding the European higher education as a whole.

For these objectives realization were to serve, among others, the following tools: more readable and comparable degrees of education, two and three-gradual studies, European Credit Transfer and Accumulation System (ECTS), supplements to diplomas, qualifications framework for higher education, standards and guidelines for quality assurance in the European Higher Education Area (IBE, 2012: p. 129).

The authors of the Polish report on the state of education of 2011 confirm that "the Bologna process reflects the increasing development of the tendency to perceive higher education not only from a cultural perspective but also from the economic one. Education and higher education are of crucial importance for the development of the economy, labour market and Europe's competitiveness. (...) An important reason for starting the Bologna process and to engage in it to the European Commission was the process of internationalization of education, including higher education. It was said here, among other things, about the increase of the competitiveness of European universities in elicitation of means and students for whom at the end of the 90s more attractive were universities in the US, Australia and Japan (IBE, 2012: p. 129-130).

Social and economic problems led to a critical assessment of the implementation of the provisions in the Lisbon Strategy in 2010. Fact-finding opinion of the European Economic and Social Committee prepared in November 2009 stated clearly, that "the current situation requires an approach consistent with the principle of sustainable development, which will unite competitiveness, research and development and innovation with the innovative social potential of Europe of the sustainable economy, as well as the idea of "good work" (EC, 2009).

The report of the European Economic and Social Committee stressed the need for promoting social cohesion as a factor of stable and dynamic economy. This social cohesion can be achieved primarily thanks to good social policy, assuming a comprehensive policy for the "good work". This policy shall appoint, among others, ambitious targets in the field of education and general, professional training and learning throughout life. The Committee believe that they contribute significantly to the growth and increase of productivity (EESC, 2010: p. 16). One of the main objectives of changes in policy direction, favouring constructive way out of the crisis and ensuring the dynamics of sustainable growth, employment 
and social cohesion, would be "further increase of the importance of the knowledge triangle (education, research, and innovation). Europe must continue to strengthen its potential lying in qualifications of its skilled people, science, research and technology, and thereby its innovation as it is an important driving force for competitiveness. The knowledge triangle must in any case continue to be the focus of the strategy for the period after 2010 (EESC, 2010: p. 19).

The conclusions of experts from the European Economic and Social Committee also focused on higher education. It was stated that "in order to provide the groundwork for future innovation, high priority should be given to science and research and the use of their results in practice. To implement the goal, adopted in Bologna, of creation of the European higher education space needed are concrete steps and a stronger political will to coordinate policies. Insufficient investment in innovation and skills exacerbates economic problems and has an impact on performance. Universities and institutions of higher education must take its share of responsibility and care much more about the European dimension, because they play a key role in the knowledge triangle, which consists of education, research and innovation. When it comes to cross-border dimension, you need to support multilateral cooperation projects in the field of research. Europe also lacks hightech companies investing in research and development. Enterprises must see more incentives to invest extra money in these areas and to create productive jobs" (EESC, 2010: p. 19).

\section{EUROPE 2020 STRATEGY - HIGHER EDUCATION FOR DEVELOPMENT AND SOCIAL COHESION}

Based on the above analysis, in 2010 the European Commission prepared a Communication EUROPE 2020. A strategy for smart, sustainable development contributes to social inclusion. It concerns the vision of building of Europeoriented social market economy. In the area of thematic Smart development development of an economy based on knowledge and innovation, the new strategy refers to the purpose of education and research and development activities. The Commission recognizes the knowledge and innovation as the biggest drivers of future growth. However, this requires "improvement of the quality of education, strengthening research, promoting innovation and knowledge transfer in the Union, full use of information and communication technologies, and the care to ensure that innovative ideas are convertible into products and services that contribute to growth, create new jobs and solve social problems in Europe and the world" (EC, 2011: p. 13). The operational objective of education is to "limit the interruption of learning up to $10 \%$ compared to the current level of $15 \%$ and an increase by 2020 the percentage of people aged 30-34 with higher education from $31 \%$ to at least 40\%" (EC, 2011: p. 12). Within the priority of Education, training and learning throughout life in the perspective of EU and on the Member States level foreseen is the implementation of the so-called flagship projects:

- Union of innovation - investments in research and development, along with tax relief; closer cooperation between universities, research and business; ensuring an adequate number of graduates of science, math and engineering and the introduction of elements of creativity, innovation and entrepreneurship into the school curricula; 
- $\quad$ Youth on the move - a revival of the program for modernization of higher education (curricula, governance and financing) among others by benchmarking university performance and educational outcomes in a global scale, to promote the official recognition of informal and non-formal learning; increasing the openness and the importance of education systems by building national qualification frameworks and better connection between learning outcomes and labour market needs (EC, 2011: p. 14).

The strategy emphasized the increase in the number of people between 30-34 years with higher education to 40 percent. As it was mentioned earlier, in 2013 this number was 37 percent. The EU Member States therefore fulfill this task. However, many issues relating to higher education still remain unsolved. Monitoring of implementation of the strategy in each country indicates the existing problems in access to studies, the prevention of school failure, flexibility of training, employability of graduates. According to the report of Modernization of Higher Education in Europe 2011: Funding and the social dimension, the alternative paths of higher education were introduced by more than half of the countries members of the Eurydice Network. But fifteen countries, mainly from Eastern Europe, still do not allow such a solution. Moreover, a significant part of the system not permitting alternative paths to higher education does not have the regulations concerning the validation outside of formal and informal qualifications. Only five countries effectively monitor the fates of graduates. The mechanisms of financing universities still are not oriented to support the promotion of higher education. Tuition fees in relation to financial support for students are still unsatisfactory. In some countries, spending on higher education has not changed, despite the increase in the number of students. Some countries have significantly reduced the funds or are planning such restrictions (Eurydice, 2011). In the report of 2014 represented are proposals for insufficient monitoring of the student population or selective analysis of individual characteristics of the population. The role of alternative paths in increasing the availability of the study is drastically reduced, and putting the availability and the prevention of school failure in the spotlight is not the norm. Most European countries provide students with the possibility of a more flexible organization of studies compared to traditional solutions, full-time studies. Unfortunately, this is associated with engaging private finance, which in turn hinders accessibility. In 18 education systems it is required from higher schools to involve employers into planning and implementation of the learning process, but only in a few countries financial incentives are used in arranging apprenticeships with employers or in joint projects realization. Measures aimed at increasing the chance for employment are mostly addressed to all students, without additional measures targeted at disadvantaged groups (EC//EACEA/Eurydice, 2014).

\section{POLISH CHALLENGES FOR HIGHER EDUCATION}

On a European scale a high priority is given to innovation in education and research as a force which is able to stimulate the economy, cause jobs to deepen competitiveness and ensure a high standard of living for citizens. Much attention is paid to scientific and technical training, UE cooperation between universities and the use of existing capacity (capital), intellectual social and economic development of the EU. The authors of the Report on Intellectual Capital of Poland of 2008 speak unanimously about the role of intellectual capital in ensuring 
the country's sustainable development. Intellectual capital is defined as "generally intangible assets of people, enterprises, communities, regions and institutions that are properly used, and they can be a source of current and future welfare of the country" (CPCM, 2008: p. 6). To enable the success, it is necessary to ensure the capacity of building of intellectual capital, which is namely manifested by a longterm thinking, willingness to learn, trust in market mechanisms and opening up to global competition, and efficient governance. Speaking about education, a special role is played by the human capital (the potential accumulated in all the citizens, expressed in their education, life experience, attitudes and skills). With regard to higher education, the report indicates, among others, to:

- $\quad$ the need to improve the quality of education;

- better accessibility to the best universities;

- matching education to labour market needs;

- $\quad$ increase of interest in science and technical studies;

- modernization of teaching methods;

- changing students' attitudes to education;

- increase of the students' efficiency in the creation of new knowledge (CPCM, 2008).

Despite the broad dissemination of higher education, quality of the educational process in Poland is unsatisfactory. The weakness of higher education in this respect is confirmed by experts, analysts and academics themselves. Deterioration of the quality of academic education is associated with poor preparation for study at the secondary school level, by the dominance of a test method in checking the knowledge, deficit of critical thinking development. Poor quality of education generates further problems. Completion of higher education no longer guarantees a well-paid and secure job. Although the level of education remains a serious argument in searching and finding job, but the ease, with which you can obtain a master's degree at numerous Polish universities, not mentioning about baccalaureate, does not contribute to a rapid employment in obtained profession and progressive professional stability. According to the data from the Report on the state of education 2010 "the system of education and higher education does not prepare graduates well enough for entering the labour market. Employers point to the fact that a significant portion of job applicants, even with proper education, cannot do what is necessary for the job performance" (IER, 2011: p. 283). In the case of people with higher education observed is phenomenon of a growing diversity of knowledge and skills of the graduates of different types of institutions. "The high level of education is more often accompanied by really low qualifications. (...) The factor of education becomes a decisive factor in terms of jobs and wages, but especially in times of recession... In contrast, the better is the economic situation, the less the situation on the market depends on this factor" (IER, 2011: p. 283). The quality of education was also influenced by the phenomenon of multiple employments of higher school teachers in the form of additional posts at several educational establishments. Currently this has been significantly limited. The age of academic staff and the generation gap in the annals have increased. According to the data from the Diagnosis of higher education in Poland "the quality of education at educational establishments is greatly influenced not only by the number and qualifications of the personnel, but also by academic programs, organizational solutions and infrastructure. An important role in ensuring the quality of education 
is played by the State Accreditation Committee (SAC), built on the basis of accreditation committees created at the initiative of the academic community. The SAC's resources and budget, however, are disproportionately small in relation to its current tasks and future challenges related to the internationalization of accreditation process. The SAC's tasks are unfortunately reduced to a verification of compliance of the method of conducting studies with the law provisions, which does not allow for valuing innovation going beyond the rigid rules, and on the other hand, hampers the stigma of poor quality (E\&YB, IBGR, 2009: p. 7).

A poorly functioning system of grants and scholarships still hampers the access to higher education, and in particular to the best universities. In 2007, a large percentage of students (more than 40 percent) studied in the fields of social sciences, management and law. In the fields of engineering, construction and technical already their number was a little over 10 percent, and the fields of natural sciences, mathematics and computer science were chosen by about 9 percent of students (CPCM, 2008). Relatively small was the share of Polish students and scientific staff in international exchange. In 2005, only 0.19 percent of students continued education in doctoral studies. The cooperation between higher schools and business to create new knowledge and innovation is poorly developed. This entailed a low level of entrepreneurship of students and the implementation of new technologies.

The vision of higher education in Poland is presented in the Strategy for the Development of Human Capital. Poland 2030 of 2011 referred in particular to the European Strategy EUROPE 2020. It included two current priorities related to improvement of the quality of education and adaptation of educational establishment's offers to the needs of the labour market. Also there were set the tasks dealing with more efficient management of public resources and stimulation of positive organizational changes in educational establishments. Each priority assumed the implementation of concrete actions:

- Creation of a professional and widely accessible information system about the prospects in the labour market and the offer and the quality of studies.

- Implementation of an effective quality assurance system of education at a higher level, based on the assessment of learning outcomes.

- Dissemination of the studies at degree I and their promotion as studies ending the cycle of formal education.

- Raising the level of extramural studies and adjustment of their organizational forms to meet the needs of students who combine studies with work or care.

- The diversity of types, mission and program offers of educational establishments in Poland: stimulation of the development, on the one hand, of one of the educational establishments and vocational programs with a practical profile, and on the other hand - the development of high-quality programs, academic institutions and research institutes.

- Increasing the number of graduates in the fields of science and technology by further enhancing their attractiveness.

- Adapting the model of medical personnel training to the projected needs of the health care system, and in particular in the context of demographic change.

- Implementation at the degree I level of studies of a model of vast multidisciplinary educational key competences sought after in the labour market, or enabling access to a wide range of the degree II studies. 
- Increasing the scale of connection of higher education studies with professional activity (in incomplete measurement of operating time).

- Changing the model of financing higher education by rewarding quality of the offer and competition between educational establishments.

- Creating a socially fair system of bearing cost of a higher level education, guaranteeing the possibility of good quality studying for each person with a predisposition to study regardless of his or her financial situation.

- $\quad$ Creation of a new model of doctoral studies and their financing.

- Expanding the autonomy of higher educational establishments.

- Increased mobility (including international) of academic staff and students.

- $\quad$ Strengthening the ties of an educational establishment with its socioeconomic environment (CPCM, 2011).

Some of these demands are already implemented in educational practice. According to the strategic government documents Poland is one of the leaders in the dissemination of education at a higher level. In the higher education system introduced are uniform rules for creating, measuring and assessing the quality of education. The result of deliberate government policy is a systematic increase in the number of graduates in science and engineering. There was introduced a division into practical and general academic fields of study. Practical directions are related to the needs of the labour market, social and economic bases. General academic profiles were directed towards the development of science and research (CPCM, 2013).

The process of change in Polish higher education continues. Subsequent demands are formulated in the Program for the Development of Higher Education and Science for the years 2015-2030. Key challenges include:

- increase the quality of higher education and adapting it to social and economic needs;

- improvement of the quality of research conducted in Polish scientific institutions;

- changes in the organization, management and financing of higher education and science;

- increase of the impact on the social, economic and international environments.

Operational dimension of these challenges is directly connected with the Strategy for the Development of Human Capital. Poland D2030. In terms of increased quality of education is proposed, among others, the improvement of personnel policies and the competence of teachers, enhancing the quality of doctorates and habilitation, changes in the nature of I and II degree studies, verification of the accreditation and ratings system, internationalization of higher education and scientific institutions. The improvement of the quality of research is to be carried out through: increasing the number of prestigious scientific achievements, the effective implementation of the results of $\mathrm{R} \& \mathrm{D}$, developing new types of scientific, research and implementation units - changes in the evaluation of research projects, cooperation with Polish scientists conducting research abroad. Rationalization of management and funding processes should constitute the base for the realization of other strategic objectives. It is mainly the desire to limit excessive bureaucracy, educational establishment funding in accordance with the components of the scientific mission (scientific research, 
training, impact on the social and economic environment), diversity of types of institutions (units of the research, research and didactic and teaching nature). Spread of the impact on the social, economic and international environments should be done by a greater popularization of the research results, strengthening of cooperation with entrepreneurs, fiscal incentives to invest in $R \& D$, in the context of learning throughout life - extending the offer of higher education for people of different ages, with different motivations and needs (improvement of professional skills, personal development, preservation of intellectual function, etc.) (MSHE, 2015).

\section{CONCLUSIONS}

Improvement of higher education in Poland and in Europe is a consequence of the global transformation of political, economic, socio-cultural and demographic nature. The dynamics of these transformations cause the need for a rapid response to the diagnosed problems and difficulties. Awareness of their presence is essential for designing of the future and strategic planning. The vision of higher education is not and cannot be a finite project. Responsible creation of educational policy requires continuous monitoring of changes and their adaptation to the real needs.

Challenges for higher education in Poland and Europe outlined in the article relate to different dimensions. To the fore mainly come the issues related to the quality of education and its accessibility, education process organizing and financing, and research and development activities on an international scale. An important priority is to link learning outcomes with the labour market. Creating a thoughtful concept of modernization is not enough. It is needed to mobilize the forces and resources to prevent the waste of higher education potential and make it an efficient instrument in building of the future.

\section{REFERENCES}

1. Bednarek, J. (2003). White Book of the European Commission. Encyclopedia of Pedagogy of the twenty-first century. Warsaw: Academic Publishing House "Zak", 1.

2. Chapinski, J., Panek, T. (ed.). (2015). Social Diagnosis 2015. The conditions and quality of life of Poles. Report. Warsaw: Council for Social Monitoring.

3. Cherwinska, E. (2004). The Lisbon Strategy. Warsaw: Analysis and Expertise of the Sejm.

4. E\& YB IBGR. The diagnosis of the state of higher education in Poland. (2009). Warsaw: Ernst \& Young Business Advisory, Institute for Market Economy.

5. EESC. The (Lisbon) Strategy after 2010: Proposals from organized civil society. Integrated report for the European Council. (2010). Brussels: European Economic and Social Committee.

6. EPIiR. Knowledge-based economy. (2016). Retrieved from http:// europejskiportal.eu/gospodarka-oparta-na-wiedzy

7. Eurydice. Modernisation of Higher Education in Europe 2011: Funding and the Social Dimension. (2011). Retrieved from http://eacea.ec.europa.eu/education/ eurydice/thematic_studies_en.php

8. Hejnicka-Bezwinska, T. (2008). General Pedagogy. Warsaw: Publishing and Academic and Professional. 
9. IER. Report on the state of education 2011. Continuation of change. (2012). Warsaw: Institute for Educational Research.

10. IER. Report on the state of education in 2010. The public road to knowledge. (2011). Warsaw: Institute for Educational Research.

11. EC. Employment and social policies: framework for investing in quality. Communication from the Commission to the Council, the European Parliament, the European Economic and Social Committee and the Committee of the Regions. Brussels: European Commission. (2009). Retrieved from http://eurlex.europa.eu/ legalcontent/EN/TXT/?uri=COM:2001:0313:FIN

12. EC. EUROPE 2020. Strategy for smart, sustainable and inclusive growth. Communication from the European Commission. (2010). Brussels: European Commission.

13. EC // EACEA / Eurydice. Modernization of Higher Education in Europe: Access, Retention and Employability 2014. Luxembourg: Publications Office of the European Union.

14. CPCM. Report on Polish Intellectual Capital. (2008). Warsaw: Chancellery of the President of the Council of Ministers.

15. CPCM. Strategy for the Development of Human Capital. Poland 2030. (2011). Retrieved from http://zds.kprm.gov.pl/strategia-rozwoju-kapitalu-ludzkiego

16. CPCM. The perspective of learning throughout life. Annex to Resolution No. 160/2013 of the Council of Ministers dated 10 September 2013. (2013).

17. MSHE. Higher education in Poland. (2013). Warsaw: Ministry of Science and Higher Education.

18. MSHE. Program for the development of higher education and science for the years 2015-2030. (2015). Warsaw: Ministry of Science and Higher Education.

19. OECD. Education at a Glance 2014: Highlights, OECD Publishing. (2014). Retrieved from http://dx.doi.org/10.1787/eag_highlights-2014-en 